\title{
WAYS OF ACQUIRING LAND PROPERTY FOR THE CONSTRUCTION OF PROVINCE ROADS
}

\author{
Karol Noga, Prof. \\ WSI-E Rzeszow School of Engineering and Economics, Poland \\ Department of Cadastre and Geodetic Spatial Planning \\ e-mail:rmknoga@cyf-kr.edu.pl
}

Monika Balawejder, PhD.

The Bronisław Markiewicz State Higher School of Technology and Economics in Jarosław, Poland

Institute of Technical Engineering

e-mail:monika.balawejder@pwste.edu.pl

Grzegorz Nosek, M.Sc.

Subcarpathian Province Roads Authority in Rzeszow

e-mail: grzegorz.nosek@pzdw.pl

\begin{abstract}
The topic of this article is related to issues connected with public roads. The thematic scope of the work includes the presentation and analysis of the legal regulations governing the acquisition of real estate under provincial public roads. The purpose of the article is to carry out an analysis of the legal and technical regulations governing the entire process of acquiring real estate along these roads, and assessing their completeness, adequacy and coherence. The analysis was carried out in the aspect of a number of operations, technical activities and the requirements of government agencies operating in the field of public roads, in an aim to manage and carry out investments on provincial roads. The paper presents and elaborates on problems connected with the acquisition of real estate along provincial roads on two levels. The first involves the regulation of the legal status of the existing regional road network from the $1^{\text {st }}$ January 1999, while the second is the implementation of new road investments within the network of provincial roads.
\end{abstract}

Key words: expropriation, compensation, property value, property divisions for roads.

JEL Classification: K11, L85, Q15, R30.

Citation: Noga K., Balawejder M., Nosek G., 2018, Ways of Acquiring Land Property for the Construction of Province Roads, Real Estate Management and Valuation, vol. 26, no. 1, pp. 108-121.

DOI: $10.2478 /$ remav-2018-0009

\section{Introduction}

The road network, which forms the basic spatial layout in the country and in every territorial unit, plays a vital role in the functioning as well as social and economic development of a country. An optimal road network, ensuring the freedom of movement of people, the transfer and transport of different kinds of material goods and the efficient provision of other services, determines the development of civilization.

In such an assumed sense of a road network, in order to fulfill a specific function, ensuring the development and maintaining a road network in good condition is of particular importance. The realization of this goal is accomplished by undertaking road maintenance reconstruction, extension, road building, and construction works aimed at increasing safety and the improving traffic flow, i.e. 
the maintenance and protection of roads. The implementation of these measures is also the realization of a public purpose, which, under the Real Estate Management Act (ACT 1997), is the release of land for public roads, cycle paths and waterways, and the construction, maintenance and carrying out of road works on these roads, structures and public transport infrastructure, as well as public communications and traffic lights.

A public road is a road classified on the basis of the Public Roads Law (ACT 1985) to one of the categories of roads - national, provincial, district or municipal. Everybody can use it accordingly to its purpose. National roads are owned by the Treasury. Provincial, district and municipal roads are owned by the competent regional government, county or municipality (ACT 1985). In addition, before the $1^{\text {st }}$ January, 1999, prior to the introduction of the state political reform, public roads were owned by the Treasury. Thus, the public nature of the roads makes it possible for everyone to move freely in the surrounding reality, without interfering with the legally protected property right along the roads. The above indicates how important it is to regulate the legal status of existing public roads, which were built on land not owned by public entities, in order to bring legal status to the real estate development status.

Adjusting the legal status of properties for roads is recognized very broadly in the work (GDESZ, TREMBECKA 2011), which, in a comprehensive manner, describes issues concerning the acquisition of real estate intended for roads or occupied for roads, taking into account the presence of various legal and actual road real estate. In turn, the article (BIEDA, HANUS 2014) presents a procedure of dividing plots to regulate the legal status of existing public roads. Regulatory procedures can be complicated (BIEDA, STALKA-KRAWCZYK 2014), especially when there is lack of synchronization of data from land and building records with real status (BALAWEJDER, ADAMCZYK, CYGAN 2016; SEJKA, MiKA, SALATA, LEŃ 2017).

An indispensable element of road construction is the occurrence of conflicts between the executing entity and private persons deprived of property rights, or whose rights have been limited (ŹRÓBEK, WALACIK 2008). The work (DEPARTMENT OF CASE LAW I 2012), which covers compensation for property held for linear investments, is also of importance. This publication contains issues related to the process of determining compensation, among others, for real estate taken over for investments in public roads. On the other hand, the Commentary on the Act on special rules for the preparation and implementation of investments in public roads (WOLANIN 2010) presents the legal mechanisms for creating public roads and the effects of the law in civil, legal and administrative areas. The Commentary constitutes an elaboration on the provisions of the Act addressed to all entities involved in issuing administrative decisions on the basis of which the acquisition of property rights for public roads is carried out. Both the preparation and implementation of a road investment encompasses, at each stage, the participation of geodesists, thus a wide range of geodetic activities and work in road construction is reflected in the work of (GOCAŁ 2009). It indicates a wide range of works, including the preparation of maps for design purposes, the preparation of geodetic-legal documentation for the purchase of land, the servicing of the implemented road investment and execution of the as-built documentation. To create the methodology of acquiring real estate for provincial roads, the methodology of acquiring property for the construction of motorways was also used (NoGA 1998; BALAWEJDER et al. 2015) as well as a work including the use of the real estate cadastre in the preparation process for the construction of motorways (NoGA 1998B). There are also studies that include the methodology of programming and the implementation of works on land consolidation and land conversion in a comprehensive manner (NOGA 2001, BALAWEJDER, LEŃ 2016). These works include the technology and methodology used when purchasing real estate for the construction of motorways and within the framework of implementing works on land consolidation and exchange, within the impact zone of motorways. The issue concerning the acquisition of real estate under a road also includes the quality and importance of registration data in the process of regulating the legal status of roads (MARCZEWSKA 2005) and special rules applicable to the division of real estate (MARCZEWSKA 2006). These works show particular cases of activities and actions occurring in the discussed issue of public roads related, among others, to the division of real estate.

A wide range of technical and legal regulations applicable to the acquisition of property for roads, as well as the ambiguous wording of those provisions causing problems with interpretation in practice, point to the complexity of the above issues. The taking on of such a problem leads us to the aim of the work which is to present the ways of acquiring land for public roads. In order to fulfill the 
research objective, the authors attempt to systematize, in a schematic form, the complex procedure of acquiring land for the construction of provincial roads.

\section{Technology of land acquisition for investments in the provincial roads}

The possibility of obtaining additional financial resources from European Union funds resulted in greater opportunities for planning the future development of the road network, including the network of provincial roads. Greater financial opportunities give more opportunities in terms of road investments, including both a greater volume and range of investments. This also implies the need to acquire more real estate for this purpose. Acquisition of real estate under provincial roads is generally made in two modes: civil law, through the acquisition of real estate in the form of notarized sales contracts, free transfer agreements, donation agreements or real estate exchange contracts for a provincial road, where ownership is acquired on the basis of an administrative decision issued by the competent authority during the carried out administrative procedure. The process of acquiring property for provincial roads has been presented in Figure 1.

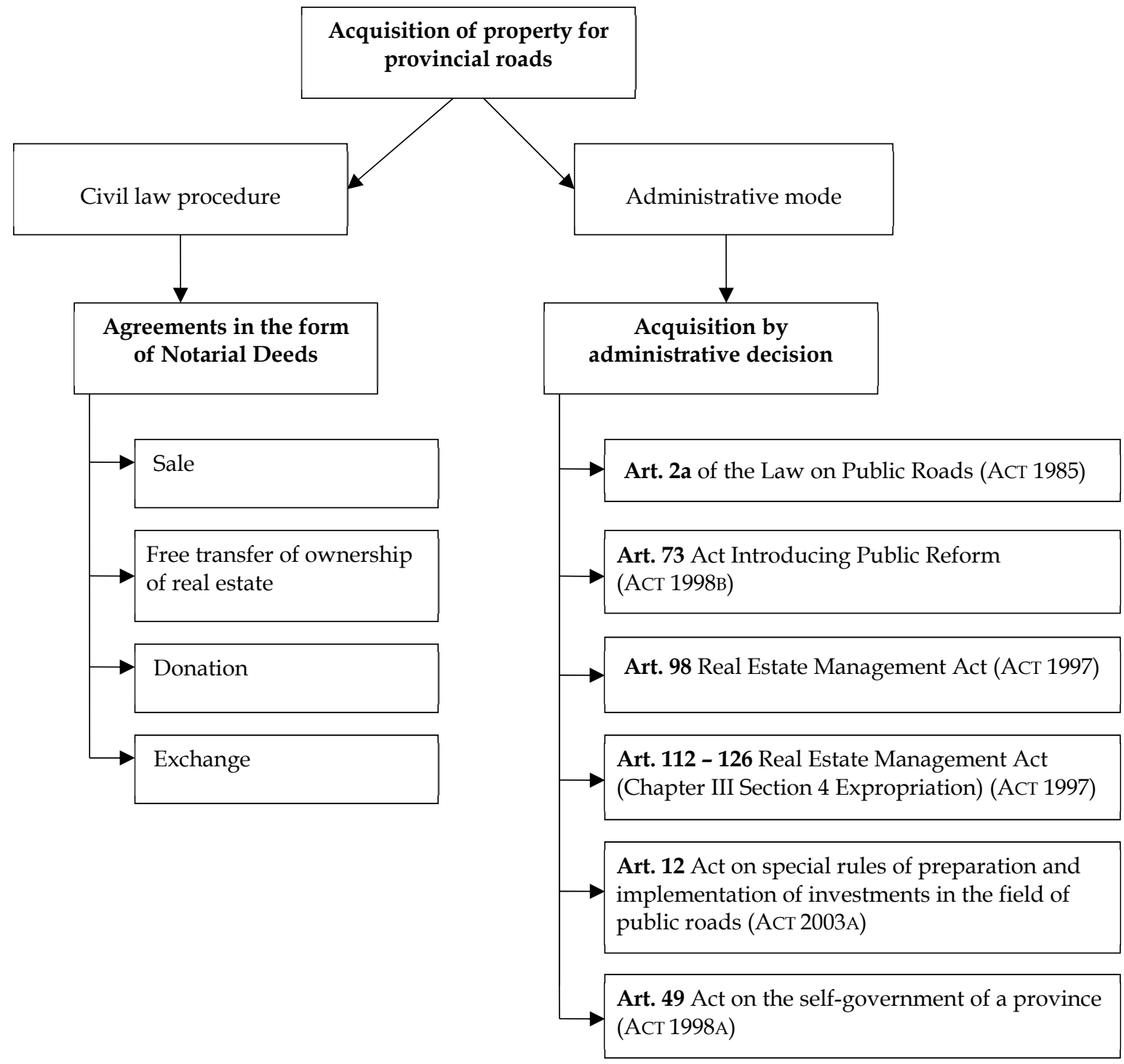

Fig. 1. Forms of acquiring property for provincial roads. Source: Own study.

These forms of acquiring real estate for provincial roads, making use of the legal bases defined in Figure 1, at the same time, determine the preparation of appropriate geodetic and legal documentation. In addition, the acquisition of real estate in certain modes occurs after the payment of the purchase price of a property, payment of compensation for the purchased property, or free of charge. 
The development and construction of provincial roads in the classic mode, under which the purchase of real property in the civil law procedure was carried out in the years 2002-2009 by the Subcarpathian Province Roads Authority in Rzeszow, is illustrated in Table 1.

Table 1

Acquisition of real estate for provincial roads in civil law procedure in the years 2002-2009

\begin{tabular}{|c|c|c|c|c|c|c|}
\hline No. & Construction or extension of the road & $\begin{array}{c}\text { Number } \\
\text { of road }\end{array}$ & $\begin{array}{c}\text { Number of } \\
\text { purchased } \\
\text { parcels }\end{array}$ & $\%$ & Area in ha & $\%$ \\
\hline 1 & Extension of road Babica - Twierdza section & 988 & 335 & 52.26 & 10.2436 & 28.00 \\
\hline 2 & Construction of the road DK9 - DK19 & 869 & 22 & 3.43 & 4.4778 & 12.24 \\
\hline 3 & Construction of the ring road of Grebow & 871 & 227 & 35.41 & 18.4075 & 50.32 \\
\hline \multirow[t]{2}{*}{4} & $\begin{array}{l}\text { Construction of the road Prusie - } 993 \text { border of } \\
\text { the province section }\end{array}$ & 867 & 57 & 8.89 & 3.4507 & 9.43 \\
\hline & Total & & 641 & 100.00 & 36.5796 & 100.00 \\
\hline
\end{tabular}

Source: Subcarpathian Province Roads Authority in Rzeszow.

As shown in Table 1, a total of 641 parcels with a total area of 36.5796 ha were taken over by provincial roads in civil law. The largest number of parcels were taken for the expansion of road 988, i.e. 335 plots with a total area of 10.2436 ha. On the other hand, the largest area of land in civil law was taken over by the construction of Ring Road 877, with a total area of 18.4075 ha, which constituted 227 plots. The data in Table 1 indicate that the extension of the road may involve a higher number of plots, but a relatively smaller area of land taken over than the construction of a new section of the road following a new track, where the area of land taken over is larger, but the number of parcels may be smaller.

The development and construction of provincial roads under the Act on special rules for the preparation and implementation of investments in public roads, under which the purchase of real estate was carried out by means of administrative mode carried out by Subcarpathian Province Roads Authority, are illustrated in Table 2.

Table 2

Acquisition of real estate under provincial roads by administrative mode on the basis of the provisions of the Act on on special rules for the preparation and implementation of investments in public roads in the years 2008-2014

\begin{tabular}{|c|c|c|c|c|c|c|}
\hline No. & Construction or extension of the road & $\begin{array}{l}\text { Number } \\
\text { of road }\end{array}$ & $\begin{array}{c}\text { Number of } \\
\text { purchased } \\
\text { parcels }\end{array}$ & $\%$ & Area in ha & $\%$ \\
\hline 1 & $\begin{array}{l}\text { Extension of road Lubaczów - Budomierz } \\
\text { section }\end{array}$ & 866 & 237 & 8.73 & 9.1788 & 5.39 \\
\hline 2 & Extension of road Mielec - Kolbuszowa section & 875 & 141 & 5.20 & 4.6033 & 2.70 \\
\hline 3 & Construction of the ring road of Mielec & 985 & 555 & 20.45 & 69.4096 & 40.75 \\
\hline 4 & $\begin{array}{l}\text { Extension of road Zarzecze - border of the } \\
\text { province section }\end{array}$ & 858 & 47 & 1.73 & 0.4236 & 0.25 \\
\hline 5 & $\begin{array}{l}\text { Extension of road border of the province - } \\
\text { Leżajsk section }\end{array}$ & 877 & 69 & 2.54 & 0.5721 & 0.34 \\
\hline 6 & Construction of the road link in Gorliczyna & 835 & 92 & 3.39 & 6.1115 & 3.59 \\
\hline 7 & Extension of road & 892 & 295 & 10.87 & 1.7311 & 1.02 \\
\hline 8 & Extension of road & 855 & 311 & 11.46 & 1.3864 & 0.81 \\
\hline 9 & Extension of road & 880 & 290 & 10.69 & 2.7353 & 1.61 \\
\hline 10 & $\begin{array}{l}\text { Construction of the road Połaniec - Tuszów } \\
\text { Narodowy section }\end{array}$ & 764 & 401 & 14.78 & 53.3613 & 31.33 \\
\hline \multirow[t]{2}{*}{11} & Construction of the ring road of Brzozów & 886 & 276 & 10.17 & 20.8103 & 12.22 \\
\hline & Total & & 2714 & 100.00 & 170.3233 & 100.00 \\
\hline
\end{tabular}

Source: Subcarpathian Province Roads Authority in Rzeszow.

As shown in Table 2, a total area of 170.3233 ha has been taken over by provincial roads pursuant to the provisions of the Act on special rules for the preparation and implementation of investments in 
public roads. The largest number of plots, i.e. as many as 555, with a total area of 69.4096 ha, was taken over for the construction of the ring road of the city of Mielec as a section of Road 985, which makes for more than $40 \%$ of all of the previously acquired land for investment on the basis of special road legislation. Similarly, a large area of land was taken for the construction of Road 764 on the Połaniec - Tuszów Narodowy section, which accounts for $31.33 \%$ of all purchased land, and for the construction of the ring road of Brzozow, which accounts for $12.22 \%$ of all land purchased. Much smaller land areas are taken over for the extension of existing roads but, at the same time, a relatively large number of plots are taken over.

Apart from the aforementioned investments, the extension of provincial roads, including shorter sections of roads, e.g. a few hundred meters, and a smaller range of works - construction of pavements and pedestrian and cycle routes, for which a traffic lane was also widened, were also realized. Acquisition of real estate for the above-mentioned investments was carried out by the Subcarpathian Province Roads Authority in Rzeszów until the end of 2014, financed from the own resources of the budget of the Podkarpackie Province and subsidized by European Union funds. The possibility of using additional financial sources, i.e. from European Union funds within the perspective for the years 2014-2020, enables the further development of the provincial road network in the Podkarpackie Province, where the following are planned to be prepared and implemented:

1. Extension of Provincial Road No. 869.

2. Extension of Provincial Road No. 835.

3. Extension of Provincial Road No. 984.

4. Extension of Provincial Road No. 988 Babica - Twierdza section.

5. Extension of Provincial Road No. 875 Kolbuszowa - Sokołów Młp. section.

6. Extension of Provincial Road No. 865 Jarosław - Cieszanów section.

7. Extension of Provincial Road No. 867 Oleszyce - Prusie section.

8. Extension of Provincial Road No. 881 Kańczuga - Pruchnik section.

9. Extension of Provincial Road No. 993 border of the province - Nowy Żmigród section.

10. Extension of Provincial Road No. 861 Jeżowe - Kopki section.

In analyzing the above, we can observe that most of the realized investments were based on the provisions of the Act on special rules for the preparation and implementation of investments in public roads; the same holds true for investments currently prepared for implementation. The increased volume and scope of investments in provincial roads was caused by the possibility of using additional sources of funding, i.e., from European Union funds. The financial perspective for 2014-2020 will enable further development of the regional road network in the Podkarpackie Province, which will undoubtedly also involve the need for additional land for the expansion of existing and construction of new provincial roads.

It should be emphasized that, under the administrative procedure from 1 January 1999, regional roads in Podkarpackie Province consumed 2,924 plots with a total area of 2,995.0527 hectares. This includes and acquired 889 plots with a total area of 9.3618 ha, occupied under right-of-ways and owned by natural persons, as shown in Table 3.

Table 3

Acquisition of real estate constituting right-of-ways of provincial roads as of 1 January 1999

\begin{tabular}{cccccc}
\hline No. & \multicolumn{1}{c}{ Legal basis } & $\begin{array}{c}\text { Number } \\
\text { of } \\
\text { purchased } \\
\text { parcels }\end{array}$ & $\%$ & Area in ha & $\%$ \\
\hline 1 & $\begin{array}{l}\text { Art. 2a of the Act on public roads - property of the State } \\
\text { Treasury }\end{array}$ & 2035 & 69.60 & 2985.6909 & 99.69 \\
2 Art. 73 - land owned by individuals & 889 & 30.40 & 9.3618 & 0.31 \\
\hline & Total & 2924 & 100.00 & 2995.0527 & 100.00 \\
\hline
\end{tabular}

Source: Subcarpathian Province Roads Authority in Rzeszow.

In summary, it should also be pointed out that the land of the existing right-of-ways of provincial roads is subject to regulation and acquisition of ownership by law as of 1 January 1999; on the network of provincial roads in the Podkarpackie Province, these activities are still in progress as regards individual properties, and actions should be taken as early as possible, as it is more difficult to prove 
that the conditions which are grounds for acquisition have been satisfied as the years go by. It is also important that the acquisition is free of charge; if the conditions for acquisition are not fulfilled under law, acquisition by other means will be subject to charge.

\subsection{Carrying out investments under the Act on special rules for the preparation and implementation of investments in public roads}

In the present legal state, the investor may invest conventionally by obtaining a building permit pursuant to the provisions of the Building Law Act, by acquiring the property, or pursuant to the provisions of the Act on special rules for the preparation and implementation of investments in public roads (ACT 2003A). At present, most of the implemented road investments, including the provincial roads, take the form of "design and build". This means that a single contractor, who is responsible for preparing the design documentation, obtaining all permits and decisions, and realizing the investment, is selected by tender. All the aforementioned issues make it so that the Act on special rules for the preparation and implementation of investments in public roads is applied quite commonly today to prepare and implement investments in the network of provincial roads. Under the provisions of this Act, large investments are being made, covering the extension of sections of provincial roads and the construction of new sections of these roads, for which dozens or even thousands of parcels of land are purchased, as well as small investments, involving the extension of roads, under which, for example, an extension of the right-of-way of a traffic lane is carried out, involving several plots. In this regard, the provisions of the Act do not contain any conditions.

The first version of the Act, passed in 2003, covered only the rules of preparing and implementing investments in the area of national roads. As of 16 December 2006, an amendment to the Act which covered the remaining categories of public roads became effective. Thus, it is only since that time, that this Act has been used to prepare and implement investments in the area of provincial roads.

With regard to provincial roads, the authority, duties and tasks resulting from the Act on special rules for the preparation and implementation of investments in public roads are carried out by the competent road administrator, i.e. the Province Government. Acting on behalf of the road manager, the Provincial Roads Authority is responsible for the preparation and implementation of investments in the area of provincial roads.

The Act contains specific provisions which combine several laws, thus simplifying the preparation procedures for investment, which include:

1. determining the location of a public road by defining boundary lines;

2. approval of the division of a property, to separate the part of the property located in the boundary lines;

3. approval of the building design;

4. acquisition of the ownership of immovable property intended for public use and expiry of other rights to immovable property;

5. compensation for the acquired property and other rights to such properties;

6. permission for the construction or reconstruction of the utility network of the area;

7. permission for construction or reconstruction of other public roads;

8. permission to temporarily occupy land and to determine restrictions on the use of real estate;

9. removal of trees and shrubs from real estate located in lines delimiting the area, including State Forests;

10. permission to use the road and other road structures.

It can therefore be stated that the procedures described above, which the Act on special rules for the preparation and implementation of investments in public roads combines, are governed by separate legal acts, i.e.:

- the Spatial Development Act (Аст 2003B);

- the Real Estate Management Act (AcT 1997);

- Building Law (ACT 1994);

The Act on special rules for the preparation and implementation of investments in public roads implements all these measures in one administrative procedure, resulting in a decision to authorize the implementation of a road investment (ZRID Decision). The ZRID decision, covering a provincial road, contains these four essential points: 
1. Determining the location of the investment connected with a provincial road - by defining boundary lines.

2. Approval of the division of the property, according to the course of the boundary line.

3. Approval of construction design.

4. Designation of real estate or their parts, according to the estate cadastre, which become the property of the Province.

The content of the decision to authorize a road investment defines the date of issuing the property, or the release of the property and the emptying of dwellings and other premises, which may not be less than 120 days from the date on which the decision to authorize the road investment became final. Where, pursuant to Art. 17, the Province Governor, in respect to provincial roads, shall impose immediate feasibility of the decision to authorize the implementation of a road investment at the request of the road administrator, justified by social or economic interest, then the decision:

- commits to the immediate release of the property, and the emptying of dwellings and other premises;

- authorizes the actual acquisition of the real estate by the competent road authority;

- authorizes the commencement of construction works.

Where the ZRID decision concerns a built-up property with a residential building or a building where residential premises are located, the competent road administrator is obliged, within the date of the actual acquisition of the property, indicate a replacement property. On the other hand, if the actual acquisition of the property takes place after the expiry of the 120-day period from the day the decision became final, the competent road administrator is not obliged to indicate a replacement property. It should be emphasized here that the essence of immediate enforceability is the possibility of taking possession of real estate and commencing construction works immediately after the decision is issued, at a time when it has not yet become final, and also where appeals have been lodged and appeals are pending in the court of second instance. In addition, in such a situation, i.e. appealed against the decision of the ZRID, no approval of the division of the property and no transfer of ownership of the property intended for the road take place; these effects are delayed until the end of the appeal proceedings before the court of second instance. There are also no grounds for introducing any changes resulting from the decision to the Land and Building Register (EGiB), which, according to the Land and Building Register Regulation (REGULATION 2001), is based, inter alia, on final administrative decisions. The order of immediate feasibility does not provide grounds in this regard. Its rights and effects are created under civil and building law; it thus gives the possibility to take possession of the property despite the lack of ownership transfer and, on this basis, the possibility of commencing the implementation of investment works with no land use violation.

Pursuant to Art. 20 Sec. 3 of the Act, the Province Roads Authority receives, by law, free of charge, for permanent management, property acquired for the ownership of the province for the purpose of building a provincial road, on the date when the decision to authorize the completion of a road investment became final.

With regard to land belonging to the State Forests, the State Forests Enterprise is obliged to make free felling of trees and shrubs and their removal within the time limit set out in a separate agreement between the State Forests and the appropriate road manager. At the same time, the wood obtained from this plot becomes property of the State Forests free of charge. However, the cost of felling trees and bushes up to the age of 20 years and their clearance shall be borne by the appropriate road manager. By cutting and removing trees and shrubs from state forest land, at a date to be determined directly with the road manager, this provision provides for some kind of preparation of land for construction in the agreement concluded in this regard. In addition, it should be noted that the removal of a wood stand does not constitute complete preparation of the site for construction, as stumps subject to grubbing will be left behind. At the same time, this provision creates a kind of privilege for the State Forests, because they can take the components purchased for the benefit of the province. In relation to other entities from which land is taken, the Act on special rules for the preparation and implementation of investments in public roads does not contain such provisions. Both the land and the assets associated with it are owned by the province.

The Farm and Woodland Conservation Act (АСТ 1995) does not apply to agricultural and forestry land covered by decisions approving the road investment. Thus, in relation to land acquired pursuant to legislation (Аст 2003A), there is no obligation to exclude land from agricultural and forest production, nor does it incur any obligation to pay any fees connected with this. 


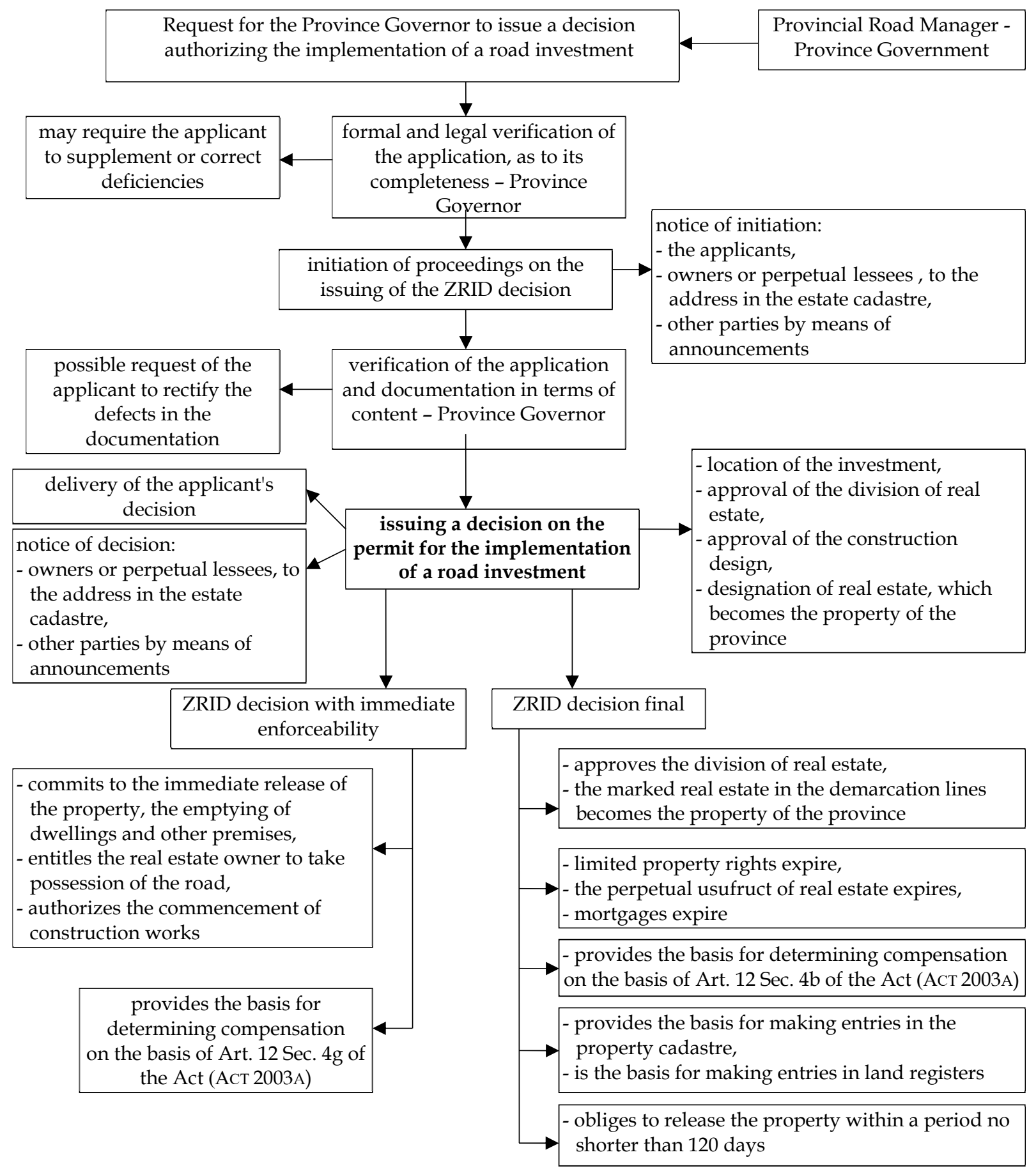

Fig. 2. Procedure for obtaining a permit for the implementation of a road investment - purchase of real estate under provincial roads according to the Act on special rules for the preparation and implementation of investments in public roads. Source: Own study based on (Aст 2003A).

It is important to introduce the land use "Tp" on maps showing the project of the division of real estate for plots intended to be used for roads. This makes it possible to take advantage of the exemption from property tax of land and buildings included in real estate intended for the construction of provincial roads purchased for the benefit of the province, no longer than for a period of 5 years for land and 1 year for buildings. Otherwise, i.e. if the existing land remains, the given land, which predominantly comprises agricultural or forest land, will be subject to taxation with agricultural or forestry taxes and charges resulting from these taxes. This state existed up until 31 December 2013, when the Land and Building Register (REGULATION 2001) was amended to include the 
land mark "Tp" covering land used for the construction of public roads, giving rise to exemption from property tax.

The legal and technical procedure of acquiring real estate for provincial roads in the entire investment preparation process under the Act on special rules for the preparation and implementation of investments in public roads (Аст 2003A) is presented in Figure 2.

The Act on special rules for the preparation and implementation of investments in public roads includes and combines procedures regulated by separate laws, thereby simplifying and accelerating them. The effect of its provisions is conducting a single administrative procedure and issuing one administrative decision which combines several elements. This, however, generate a complexity of the proceedings, resulting from the wide range of merged issues, the effectiveness and legitimacy of which is based solely on well-prepared documentation forming the basis for obtaining a road investment permit.

From the entire procedure of obtaining a permit for the implementation of a road investment, the determination of compensation was isolated as a separate administrative procedure, based on the decision to authorize the implementation of a road investment.

\subsection{Determination and payment of compensation}

Determination of compensation for real estate which, upon being designated for a provincial road, came under the legal ownership of the province, is carried out by means of an administrative decision issued by the Province Governor. Thus, compensation is determined in a separate proceeding, the basis for ex officio initiation of which is a previously issued decision to authorize the implementation of a road investment. Compensation for real estate that has become the property of the province is available to existing owners of real estate, perpetual lessees of real estate and persons entitled to the property with restricted property rights. Bearing in mind that the acquisition of real estate takes place by virtue of law, while the specific nature of the regulations contained in the Act on special rules for the preparation and implementation of investments in public roads (ACT 2003A) simultaneously removes all burdens existing on the property, including the exclusion of real estate from mortgaging; the liquidation of these charges is effected by compensation to the persons and entities entitled to them, including the repayment of mortgage-backed claims, which also expires in this part. The amount of compensation should be based on the market value of the property. This value is set on the date of the decision to establish the compensation, taking into account the condition and intended use of the property at the date of issuing the document which approved the removal of the property right (ADAMCZYK, BIEDA 2014). In this case, the amount of compensation is determined according to the state of the property at the date of the issuance of the decision on the permit for the realization of a road investment by the first instance authority and according to its value from the date that the determination of the amount of compensation takes place.

Determining the market value of property in terms of fair compensation is a serious problem. Determining the value of real estate acquired for linear investments should take into account the characteristic conditions that include the uniform definition of the features of the valued real estate along the entire length of the planned route, the speed of carrying out the valuation, or the correct definition of the mutual differences between the values of neighboring real estate (ŚLIWIŃSKI 2011). A methodology used to determine fair compensation for properties taken for public purposes was developed by Walacik in his publications (WALACIK 2014; 2011, BEŁEJ, WALACIK 2009). The author clarifies the notion of "adequate compensation" by stating that its upper closed limit should be the value of full compensation, whereas the lower is the economic value offsetting the loss - the market value of the expropriated property (WALACIK 2014). In practice, the basis for determining the amount of compensation is the market value of the property, as defined in the estimation report prepared by a property valuer. Thus, the Province Governor conducting the compensation proceedings first appoints a valuation expert, who is selected by way of a tender procedure. In practice, this increases the length of time before persons entitled to compensation become familiar with the assessed value of the real estate. Particularly important is the ability to determine the accurate state of the property. When describing the state of real property, it is necessary to indicate both the legal status of the real estate, which will be possible to determine if the real estate has a land and mortgage register - and thus a regulated legal status; in the absence of a register, this is done on the basis of geodetic legal documentation prepared for the purposes of the ZRID decision, which includes other documents confirming the ownership of the property, thereby making it possible to determine the property 
owner. In addition, over the course of the compensation proceedings, property owners may also provide proof of ownership that has not been disclosed, such as a decision on the acquisition of inheritance. The above-mentioned documentation may also serve to state that the property has an unsettled legal status for which compensation is also established. Once again drawing attention to the state of the property, it should be kept in mind that the amount of compensation is determined according to the state of the property at the date of issuance of the decision to authorize the implementation of the road investment; it is, therefore, important to determine what financial assets were on the property at that date. In the case of an investment not yet having been completed, it will be possible to determine the correct condition of the property. In this case, the boundaries of the division of the property, which determine the extent to which the land has been acquired, together with the components thereon, will prove helpful. In practice, there are also situations where, by the time a property valuer is appointed, the realization of an investment will have already commenced, and, thereby, the elements that were found in the ground removed; in such cases, a protocol from the inventory of the state of real property is drawn up, written in the presence of the owner and containing his/her signature, which, upon next being handed over to the asset valuer, will be the basis for determining the state of the property prior to the commencement of construction works. Then, an element of geodetic-legal documentation in the form of a map with a plan of the division and border sketches on which permanent existing elements such as fences, gates, buildings and wells, possibly including the measurements of the distances of these elements from the border lines, can also be used to control the correctness of the established state of the real property if the owner was not present or raises objections to the given state, which will, at the same time, make it possible to unequivocally identify the components of the acquired part of the real estate.

The provisions of the Act (ACT 2003A) additionally include so-called bonuses designed to encourage or mobilize property owners to voluntarily issue properties who, in return, will receive increased compensation. In cases when the current owner or perpetual lessee of a property subject to the decision of ZRID shall, as appropriate, release the property or sell the property and empty the dwelling and other premises without delay, but no later than 30 days after:

1) delivery of a notice of the issuance of a decision having immediate enforceability,

2) delivery of the decision to grant the ZRID decision immediate enforceability or

3) the day when the decision on ZRID became final

- the amount of compensation is increased by an amount equal to $5 \%$ of the value of the property or the value of the right of perpetual lessee.

Where the ZRID decision concerns a property built-up with a residential building or a building where residential premises are located, the amount of compensation for the existing owner or perpetual lessee resident in that building or premises is increased by PLN 10,000 for that property (Aст 2003A).

Payment of the established compensation shall be made on a one-off basis, within 14 days of the date on which the decision to establish the compensation becomes final.

The entity obliged to pay compensation, which in the case of provincial roads is the Province Roads Authority, pays compensation to the bank account indicated by the person entitled to compensation or attempts to pay compensation, e.g. by postage or by cash payment at the Province Roads Authority.

In situations where the person entitled to compensation refuses to accept it or the payment of compensation is faced with difficult to overcome obstacles, the compensation is paid to the court deposit. In addition, if the compensation for expropriation concerns a property with an unsettled legal status, it also constitutes a legal deposit for a period of 10 years (АСт 1997).

An amendment to the Act on special rules for the preparation and implementation of public road investments, introduced on the 25th February 2013, made it possible to establish compensation when the decision of the ZRID is not yet final due to the appeals lodged and the pending appeal before the second instance authority, and has immediate enforceability on the basis of Art. 12, Sec. $4 \mathrm{~g}$ of the Act (AСт 2003A). The compensation determined in the administrative decision shall be paid within 14 days of the date on which the determination of compensation becomes final, but no earlier than the final ZRID decision. This means that compensation cannot be paid prior to the transfer of ownership - on the date of the final ZRID decision. 


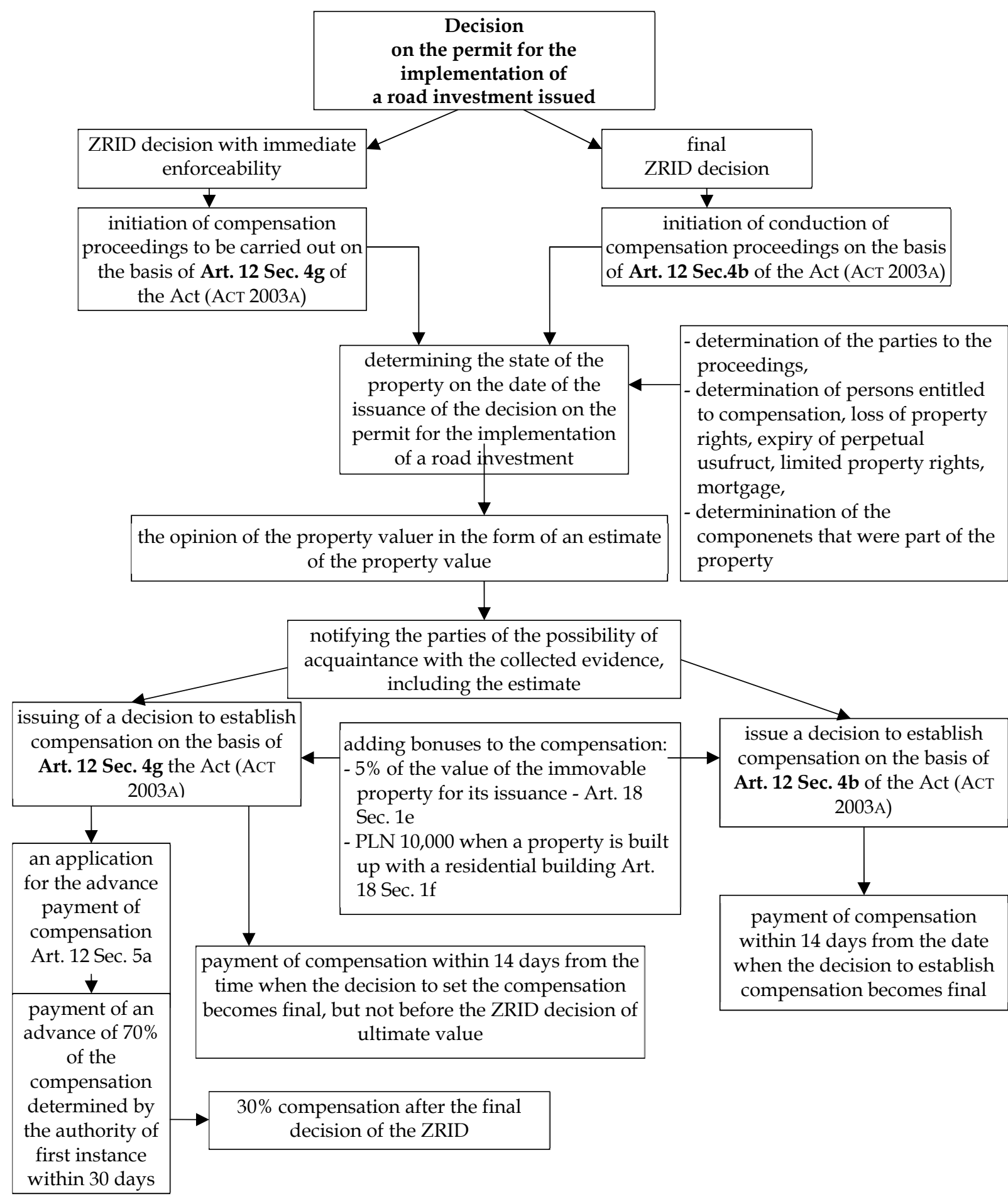

Fig. 3. Procedure for determining and paying compensation for real estate purchased for the benefit of the province for provincial roads under the Act on special rules for the preparation and implementation of investments in public roads. Source: Own study based on (Аст 2003A).

If a road investment is commenced immediately after the decision has been issued, persons or entities whose real estate is subject to the decision to authorize a road investment having immediate enforceable feasibility will be able to become familiar with the amount of compensation that they are entitled to, even though the ZRID decision is not yet final. Moreover, in accordance with Article 12 Sec. 5a of the Act (ACT 2003A), at the request of a person entitled to receive compensation, the property which becomes the property of the province shall be paid an advance of $70 \%$ of the compensation determined by the first instance authority, i.e. the Province Governor, in the decision determining the amount of compensation. The advance payment is made on a one-off basis within 30 days of the date 
of submitting the application. A surcharge of the remaining 30\% is made when the decision to authorize the implementation of a road investment becomes final. The regulations introduced in this area have mitigated some of the negative effects of the ZRID decision with the imposition of immediate enforceability, where construction works are being carried out and the decision is not yet final, i.e. the owner or perpetual lessee is actually deprived of his property and has no established and paid compensation.

The procedure for the determination and payment of compensation for properties purchased for provincial roads for the benefit of the province, pursuant to the decision of the ZRID, under the Act on special rules for the preparation and implementation of investments in public roads (ACT 2003A), is a continuation of the presented technology and procedure for the preparation of investments, which is recognized in Figure 3.

Summing up the indicated procedure, a significant disadvantage of the Act on special rules for the preparation and implementation of investments in public roads that should be recognized is that the removal of the right of ownership or deprivation of the owner of the possession of real estate on the basis of a decision with immediate effect takes place earlier than he or she receives compensation or even gains knowledge of the estimated value of the real estate; in situations when the realization of the investment takes place immediately after the ZRID decision with immediate effect is issued, the possibility of advance payment mitigates this effect.

\section{Conclusions}

The methodology, procedures and conditions, as well as the legal basis for acquiring real estate for provincial roads, were presented on the basis of legal and technical analyses. The complexity of the whole process of acquiring real estate is undoubtedly dependent on the legal status of the property to be taken over and determined by issues related to the possible necessity of regulating the legal status of the existing provincial road or acquisition of real estate for investment under which the existing road lane will be widened or of a new section of the road constructed. The complexity of the whole process of obtaining real estate for provincial roads is further increased by the fact that this process typically includes a large number of real properties.

The following observations and characteristics of the legal and technical regulations concerning the division of real estate and the methodology and procedures for the acquisition of real estate for provincial roads can be specified:

1. The obligation to acquire real estate for public roads is legally regulated and results, inter alia, from their widespread availability, irreversible permanent acquisition of land and statutory ownership assigned accordingly to the relevant category of public road.

2. No entities other than those indicated in the Public Roads Act (ACT 1985), accordingly to the category of road, have the right and basis to acquire property occupied by public roads of a particular category and intended for a public road of a particular category.

3. The Act on special rules for the preparation and implementation of investments in public roads (Аст 2003A) contains special provisions simplifying investment preparation procedures and incorporating the provisions of several statutes: Spatial Development Act (ACT 2003B), Real Estate Management Act (Аст 1997), Building Law Act (Аст 1994).

4. Although The Act (АСт 2003A), contains specific provisions, in many cases, the literal analysis of their content is not sufficient to unambiguously establish the scope of their effect, especially in the context of relations with other acts which it combines. In this context, there are also doubts concerning the interpretation of regulations, both by the authorities and road managers.

5. Geodetic-legal documentation prepared at the implementation of the investment pursuant to the provisions of The Act (ACT 2003A) is used three times, i.e. to issue a decision on the permit for the implementation of a road investment, to issue a decision on the determination of compensation and to disclose changes in land and mortgage registers.

The possibility to fulfill the specific function of the public road network, including provincial roads, is carried out in order to ensure the continuous development of the road network and its maintenance in good technical condition. Throughout this process, the need to obtain land for public roads will remain a constant element. 


\section{References:}

ADAMCZYK T, BIEDA A., 2014, Intended Use of Real Estate as a Time Changeable Attribute for Determining Compensation for Nationalized and Expropriated Lands, Real Estate Management and Valuation, Vol. 22, No. 4, pp. 35-50.

Balawejder M., AdAmczyK T., CYGAN M., 2016, The Problem of Adjusting Polish Spatial Information Resource to the Standards of the INSPIRE, Geographic Information Systems Conference and Exhibition - GIS ODYSSEY 2016, Perugia, Italy, pp. 14-24.

BALAWEJDER M., LEŃ P., 2016, The Realization of Complex Work of Consolidation and Exchange of Land in the Villages Divided by a Highway, Geomatics and Environmental Engineering, Vol. 10, No. 3, Kraków, pp. 27-37.

BAlAWEjder M., BuŚKO M., Cellmer R., JuChnieWicz-PiotrowSKA K., LeŃ P., MiKA M., SZCZEPANKOWSKA K., WÓJCIAK E., WÓJCIK-LEŃ J., ŹRÓBEK S., 2015, Aktualne problemy gospodarki nieruchomościami w Polsce na tle przemian organizacyjno-prawnych (Current Problems of Real Estate Management in Poland against the Background of Oganizational and Legal Changes), Monografia Wyższej Szkoły Inżyniryjno-Ekonomicznej w Rzeszowie pod red. Mika M., Balawejder M., Rzeszów, pp. 144.

BEŁEJ M., WALACIK M., 2009, Ewolucja procedur nabywania nieruchomości przeznaczonych pod inwestycje drogowe a zasada równowagi stron, (Evolution of Property Acquisition Procedures for Road Investments and the Balance of the Parties), Studia i Materiały Towarzystwa Naukowego Nieruchomości 17 (4), pp. 81-92.

BIEDA, A., HANUS, P., 2014, Subdivision as a Tool for Regulating and Approving Legal Status of Real Estate. Environmental Engineering. Proceedings of the International Conference on Environmental Engineering. ICEE, Vol. 9, pp. 1-9. Vilnius Gediminas Technical University, Department of Construction Economics \& Property.

BIEDA A., STALKA-KRAWCZYK D., 2014, Analiza postępowań związanych z regulacja stanu prawnego dróg publicznych na przykładzie Chorzowa (Analysis of Proceedings Related to the Regulation of the Legal Status of Public Roads on the Example of Chorzów), Zeszyty Naukowe Uniwersytetu Szczecińskiego, Studia i Prace Wydziału Nauk Ekonomicznych i Zarządzania, 36 T. 1, Szczecin, pp. 139-151.

GDESZ M., TREMBECKA A., 2011, Regulowanie stanu prawnego nieruchomości pod drogi (Regulating the Legal Status of the Property under the Roads), Wydawnictwo Gall, Katowice, p. 280.

GocAŁ J., 2009, Geodezja inżynieryjno-przemysłowa (Industrial Engineering Surveying), Part II, Wydawnictwo AGH, Kraków, pp. 209-265.

MARCZEWSKA B., 2005, Jakość $i$ znaczenie danych ewidencyjnych w procesie regulacji stanu prawnego dróg (The Quality and Importance of Registration Data in the Process of Regulating the Legal Status of Roads), ZN AR Kraków nr 417, Geodezja zeszyt 21, Wydawnictwo Akademii Rolniczej w Krakowie, Kraków, pp. 281-287.

MARCZEWSKA B., 2006, Szczególne zasady obowiąujące przy podziałach nieruchomości (Special Rules Applicable to the Division of the Property), ZN AR Kraków No. 431, Geodezja zeszyt 22 Wydawnictwo Akademii Rolniczej w Krakowie, Kraków, pp. 141-145.

Ministerstwo Transportu, BudOWnictwa i GOSPODARKi MORSKIEJ, DePARTAMENT ORZECZNICTWA I , 2012 (Department of Case Law I, 2012), Odszkodowania za nieruchomości przeznaczone na cele inwestycji liniowych (Compensation for Property Intended for Linear Investment) Wydawnictwo Centrum Usług Wspólnych, Warszawa.

NoGA K., 1998A, Metodyka pozyskiwania nieruchomości pod budowę autostrad (Method of Acquiring Real Estate for the Construction of Highways), Zeszyt Naukowy No. 59 ZN Akademii Rolniczej w Krakowie, Kraków, pp. 359-366.

NoGA K., 1998B, Wykorzystanie katastru nieruchomości w procesie przygotowania budowy autostrad (Use of the Cadastre of Real Estate in the Preparation Process for the Construction of Highways). [in:] Geodezja inzynieryjna i kataster w gospodarce narodowej. Seria Budownictwo i Inżynieria Środowiska z. 29 T. II, ZN Politechniki Rzeszowskiej, Rzeszów, pp. 329-334.

NoGA K., 2001. Metodyka programowania $i$ realizacji prac scalenia $i$ wymiany gruntów w ujęciu kompleksowym, (Methodology of Programming and Implementing Works on the Consolidation and Exchange of Land in a Comprehensive Approach), Szkoła Wiedzy o Terenie, Kraków, pp. 63-79.

ROZPORZĄDZENIE MiNISTRA ROZWOJU REGIONALNEGO I BUDOWNICTWA Z DNIA 29 MARCA 2001 R. wsprawie ewidencji gruntów i budynków (Ordinance of Minister of Regional Development and 
Construction of 29 March 2001 on the land and building register), t.j. Dz. U. 2016, poz. 1034 z późn. zm. (Journal of Laws 2016, item 1034 as amended), access date: 04.05.2017.

SIEJKA M., MiKA M., SALATA T., LEŃ P., 2017, Algorithm of Land Cover Spatial Data Processing for the Local Flood Risk Mapping, No. 2017/2/22. Survey Review, Taylor \& Francis. pp. 1-7.

ŚLIWIŃSKI Ł., 2011, Odszkodowania za nieruchomości przeznaczone pod drogi publiczne (Compensation for Property Intended for Public Roads), Studia i Materiały Towarzystwa Naukowego Nieruchomości (Journal of the Polish Real Estate Scientific Society) 17 (4), pp. 191-202.

USTAWA Z DNIA 21 MARCA 1985 R. o drogach publicznych (The Act Public Roads of 21 March 1985), t.j. Dz. U. 2016, poz. 1140 z późn. zm. (Journal of Laws 2016, item 1140 as as amended), access date: 04.05.2017.

UstAWA Z DNIA 7 LIPCA 1994 R. Prawo budowlane (The Act Building Law of 7 July 1994), t.j. Dz. U. 2016, poz. 290 z późn. zm. (Journal of Laws 2016, item 290 as amended), access date: 04.05.2017.

USTAWA Z DNIA 3 LUTEGO 1995 R. o ochronie gruntów rolnych i leśnych (Act on Farm ond Woodland Conservation of 3 February 1995) t.j. Dz. U. 2015, poz. 909 z późn. zm. (Journal of Laws 2015, item 909, as amended), access date: 04.05.2017.

USTAWA Z DNIA 21 SIERPNIA 1997 R. o gospodarce nieruchomościami (The Act Real Estate Management of 21 August 1997), t.j. Dz. U. 2016, poz. 2147 z późn. zm. (Journal of Laws 2016, item 2147, as amended), access date: 04.05.2017.

USTAWA Z DNIA 5 CZERWCA 1998 (A) R. o samorządzie województwa (The Act on the Self-government of the Province of 5 June 1998A), t.j. Dz. U. 2016, poz. 486 z późn. zm. (Journal of Laws 2016, item 486, as amended), access date: 04.05.2017.

USTAWA Z DNIA 13 PAŹDZIERNIKA 1998 (B) R. Przepisy wprowadzajace ustawy reformujace administracje publiczna (Act Introducing Public Reform of 13 October 1998B), Dz. U. 1998, Nr 133, poz. 872 z późn. zm. (Journal of Laws 1998, No. 133, item 872, as amended), access date: 04.05.2017.

USTAWA Z DNIA 10 KWIETNIA 2003 (A) R. o szczególnych zasadach przygotowania $i$ realizacji inwestycji w zakresie dróg publicznych (Act on Special Rules for the Preparation and Implementation of Investments in Public Roads of 10 April 2003A), t.j. Dz. U. 2015, poz. 2031 z późn. zm. (Journal of Laws 2015, item 2031, as amended), access date: 04.05.2017.

USTAWA Z DNIA 27 MARCA 2003 (B) R. o planowaniu i zagospodarowaniu przestrzennym (Act on Spatial Development of 27 March 2003B), t.j. Dz. U. 2016, poz. 778 z późn. zm. (Journal of Laws 2016, item 778, as amended), access date: 04.05.2017.

WALACIK M., 2014. Opracowanie zasad ustalania wysokości stusznego odszkodowania za nieruchomości przejęte na cele publiczne (Elaboration of the Principles of Determining the Amount of Just Compensation for Real Estate Taken Over for Public Purposes), Wydawnictwo NDB, Olsztyn.

WALACIK M., 2011, Utracone korzyści a stuszne odszkodowanie za nieruchomości przejęte pod inwestycje celu publicznego w Polsce i na świecie (Lost Profits and Just Compensation for Properties Taken Over for Public Purpose Investments in Poland and Oother Countries), Studia i Materiały Towarzystwa Naukowego Nieruchomości (Journal of the Polish Real Estate Scientific Society) 19 (3), pp.108-118.

WOLANIN M., 2010, Ustawa o szczególnych zasadach przygotowania i realizacji inwestycji w zakresie dróg publicznych. Komentarz, (Act on Special Rules for the Preparation and Implementation of Investments in Public Roads. Comment), Wydanie 2 (Issue 2), C.H. Beck, Warszawa, p. 350.

ŹRÓBEK S., WALACIK M., 2008, Problematyka nabywania gruntów pod budowe dróg (The Problems of Land Acquisition for Public Roads Constrution), Studia i Materiały Towarzystwa Naukowego Nieruchomości (Journal of the Polish Real Estate Scientific Society), Vol. 16, No. 1, pp. 91-100. 